\title{
CHANGING ROLES OF THE EU AND ASEAN ON PEACE IN THE KOREAN PENINSULA
}

\author{
Sangmin Bae and Martyn de Bruyn ${ }^{1}$ \\ Northeastern Illinois University
}

\begin{abstract}
Continuing tension and competition among Northeast Asian countries complicate the degree to which North and South Korea can actively garner support from regional powers. The involvement of regional powers has not been effective means to overcome the status quo. Bilateral negotiations between North Korea and the United States, while critical for tension reduction in the region, have not been able to produce an agreement. Instead, international institutions from outside the region may be able to help negotiate a peace agreement that brings acceptable levels of security to all parties involved. This article examines the past and future roles of international institutions located outside of the region -- notably the European Union (EU) and the Association of Southeast Asian Nations (ASEAN). Exploring the relations of the EU and ASEAN with the two Koreas, the article assesses their potential as mediators in the process of creating a lasting peace between the Koreas.
\end{abstract}

Keywords: Peace in Korea, North Korea and the US, Korea and EU, Korea and ASEAN

Tittulo en Castellano: Cambios en los papeles que desempeñan la UE y ASEAN en la Península de Corea

\section{Resumen}

La continua tensión y la competencia entre los países del noreste de Asia complican el grado en que Corea del Norte y Corea del Sur pueden conseguir activamente el apoyo de las potencias regionales. La participación de las potencias regionales no ha sido un medio eficaz para superar el statu quo. Las negociaciones bilaterales entre Corea del Norte y Estados Unidos, si bien son fundamentales para la reducción de la tensión en la región, no han podido conseguir un acuerdo. En cambio, las instituciones internacionales de fuera de la región pueden ayudar a negociar un acuerdo de paz que traiga niveles aceptables de seguridad a todas las partes involucradas. Este artículo examina las funciones pasadas y futuras de las instituciones internacionales ubicadas fuera de la región -- en particular la Unión Europea (UE) y la Asociación de Naciones del Sudeste Asiático (ASEAN). Explorando las relaciones de la UE y la ASEAN con las dos Coreas, el artículo evalúa su potencial como mediadores en el proceso de creación de una paz duradera entre las dos Coreas.

Palabras Clave: Paz en Corea, Corea del Norte y Estados Unidos, Corea y la UE, Corea y ASEAN

Copyright (C) UNISCI, 2019.

Las opiniones expresadas en estos artículos son propias de sus autores, y no reflejan necesariamente la opinión de UNISCI. The views expressed in these articles are those of the authors, and do not necessarily reflect the views of UNISCI.

\footnotetext{
${ }^{1}$ Sangmin Bae is Professor of Political Science at Northeastern Illinois University

E-mail: <sbae@neiu.edu>

Martyn de Bruyn is Professor of Political Science at Northeastern Illinois University

E-mail:<mdebruyn@neiu.edu>

DOI: http://dx.doi.org/10.31439/UNISCI-74
} 


\section{Introduction}

Political and diplomatic changes observed on the Korean peninsula in the past decades have involved the United States and major powers in the region -- China, Russia, and Japan -employing different approaches from engagement to sanctions without much success in the areas of tension reduction, non-proliferation, or peace building. The Trump Administration's negotiation strategy with North Korea presents an historically unprecedented approach to denuclearization, and peace and security, on the Korean peninsula. The United States has elevated North Korea's status by prioritizing direct negotiations, and having summits, over the multilateral six-party talks preferred by previous administrations. The Trump Administration's novel approach has left China, Russia and Japan in a bind as they try to assess how direct talks between the US and North Korea affect their strategic role and interests in the region. The new reality of the US negotiations with North Korea have both spurred on the regional powers in East Asia to remain relevant in the peace process, and, to some extent, exposed their prioritizing of national security interests over building peace between the two Koreas. China, Russia, and Japan continue to assess the potential threat that comes out of North Korea and weigh their own strategic interests. In this respect the regional powers have been in agreement with the United States that denuclearization is the first necessary step to get to a peace treaty. The key objective for the United States and the regional powers is to eliminate the possible threat posed by North Korea's nuclear weapons. If denuclearization comes with the establishment of sustainable peace on the peninsula, then that is an added bonus, but not the core principle of their foreign policy. In fact, China, Russia, and Japan have, albeit different, domestic political reasons to defer back to the status quo, of a nuclear armed and heavily sanctioned North Korea, instead of pursuing a peace treaty that brings North Korea back into the international community. As all major parties involved would object to a peace agreement that does not include denuclearization, we refer to both denuclearization and peace as terms that are seen as working in tandem.

State interests, power structure, and continuing competition in the region complicate the degree to which North and South Korea can actively garner support from regional powers. The involvement of regional powers does not particularly help to overcome the status quo, and bilateral negotiations between North Korea and the United States, while critical for tension reduction in the region, have not been able to produce an agreement. Instead, international institutions from outside the region may be able to help negotiate a peace agreement that brings acceptable levels of security to all parties involved. This article seeks to highlight the past and future roles of international institutions located outside of the region -- notably the European Union (EU) and the Association of Southeast Asian Nations (ASEAN). Exploring the relations of the EU and ASEAN with the two Koreas, the article assesses their potential as mediators in the process of creating a lasting peace between the Koreas. When using the term mediators here we are referring to the more limited process of providing good offices as third party in facilitating dialogue between the two Koreas and between North Korea and the United States. We are not envisioning the EU or ASEAN in a formal meditating role as hosts of formal peace talks. The expectation is that these international institutions would set up the conditions under which formal negotiations between the conflicting parties can start.

The article proceeds as follows. Section two discusses the ambivalent stances of major regional Pacific powers in the inter-Korean peace process. Section three explains the EU's previous mediating roles and recent limitations. Section four analyzes ASEAN's unique position and relations with the two Koreas in assisting to promote peace in the Korean peninsula, followed by a conclusion section. 


\section{Political Calculations of Neighboring States: China, Japan and Russia}

This section addresses unique positions and complicated roles of neighboring countries, which ultimately hinders regional cooperation pertaining to inter-Korean relations. China, Russia and Japan, as regional powers in East Asia, need to balance their own security interests with any changes that a future peace treaty between the two Koreas could bring. On the one hand, the regional powers are eager to remain relevant in pursuing a solution to the nuclear crisis, while on the other hand, there are domestic political consideration that drive these states to embrace the current status quo. The status quo would be defined as a heavily sanctioned and internationally insolated nuclear North Korea. Direct talks between the United States and North Korea have increased the concern in regional powers, especially Japan and Russia, of being left behind. At the same time, the uncertainty that peace talks will bring, ranging from much closer ties between the two Koreas to a reduction of American forces on the peninsula, pushes regional powers back to the status quo.

First, we will discuss the position of China. China arguably has the most leverage on Kim Jong-un's regime and has helped sustain the regime. For the past two decades, especially during the six-party talks in the 2000s, China has had an influential role in the nuclear negotiations with Pyongyang. While China would continue to prefer North Korea's denuclearization and to officially support North Korea's recent diplomatic push with the United States and South Korea, its overriding national interest is stability on the Korean peninsula. Rather than risking a regime collapse of North Korea which may create hundreds of thousands of North Korean refugees flooding into China, or supporting a united, US-friendly democratic Korea which might develop from a radical political transformation, China's preference is to keep familiar and known political conditions on its doorstep. ${ }^{2}$ North Korea has served as a buffer zone between China and US military forces in South Korea, and China does not want to disturb the regional status quo. North Korean regime stability appears to be China's first priority. However, China, and Russia, stand to gain economically from a stable Korean peninsula. ${ }^{3}$ A denuclearized North Korea can be integrated into the North East Asian economic framework outlined in Chinese President Xi Jinping's "Belt and Road" initiative. In other words, China would prefer to have a denuclearized and economically integrated North Korea on its border over the status quo. It is the risk of regime change in North Korea, and the possibility of having a unified Korea aligned with the United States, that drives China back to the status quo as second best option.

Additional difficulty comes from the growing competition between the United States and China to gain influence in the region, which places South Korea in a very difficult position. South Korea is increasingly facing contradicting pressures from each superpower. One example is its diplomatic row with China in recent years regarding a US anti-ballistic defense system, THAAD. Beijing, vehemently opposing the deployment of THAAD in South Korea, imposed strong measures such as a state-led boycott of Korean products and tourist industry in 2016-17, seen in South Korea as economic retaliation. Despite signs of recovery between Beijing and Seoul, the geopolitics of Northeast Asia continues to be precarious and tenuous having South

\footnotetext{
${ }^{2}$ Kim, Patricia: "How China Sees North Korea: Three Critical Moments in History and Future Directions", The Chicago Council on Global Affairs, 17 January 2018, at https://www.thechicagocouncil.org/publication/howchina-sees-north-korea-three-critical-moments-history-and-future-directions.; Liu, Ming: "China and the North Korean Crisis: Facing Test and Transition”, Pacific Affairs, Vol. 76, nº 3 (Fall 2003), pp. 347-373.; Park, HunBong: "China's Position on Korea's Unification and US Forces Korea”, The Journal of East Asian Affairs, Vol. 24, n' 1 (Spring/Summer 2010), pp. 117-154.

${ }^{3}$ Boc, Anny and Gudrun Wacker: "China: Between Key Role and Marginalization", in

Hilpert, Hanns Günther and Oliver Meier (eds.) (2018): Facets of the North Korea Conflict: Actors, Problems, and Europe's Interests, Stiftung Wissenschaft und Politik (SWP) Research Paper 12, at https://www.swpberlin.org/en/publication/facets-of-the-north-korea-conflict., pp. 27-30.
} 
Korea reach further away to diversify its current reliance on neighboring countries. The deployment of the US anti-ballistic defense system in South Korea, in response to the nuclear threat from North Korea, has also increased the costs of the North's nuclear proliferation for China as it potentially weakens China's own nuclear deterrence system. ${ }^{4}$ The competition between the United States and China has made China more suspicious of American initiatives in addressing the North's nuclear program. During the six-party talks China was a key negotiating member that was able to coerce North Korea in continuing the negotiations. Now that the US has started direct talks with North Korea, China stands to potentially lose or reduce its key role in the denuclearization process. China will continue to shelter North Korea from the most stringent sanctions in order to remain relevant to the North and continue to be a major player in all possible solutions to the crisis.

Second, the position of Japan is even more ambivalent. Japan has been in the direct pathway of most North Korean missile launches. It is not surprising that Japan has been a proponent of severe sanctions against North Korea at the United Nations, and has imposed even stricter sanctions itself. Japan is also using its substantial international influence, especially on developing countries in Southeast Asia and Africa, to ensure that the sanctions regime against North Korea is fully implemented..$^{5}$ In addition to Japan's foreign policy response to North Korean missile tests, a domestic political consideration affects Japan's reaction to the North Korean threat. North Korea's nuclear provocation has been instrumental for Japan's longtime ambition to revise the constitution and to make it a "normal country" with greater military capabilities. Prime Minister Shinzo Abe and his cabinet, emphasizing "the threat is real," repeatedly relate North Korea's nuclear tests and missile lunches with their political drive to modify the constitution's Article 9 "peace clause," which enables the country to have new military platforms. ${ }^{6}$ The military crisis on the Korean peninsula and heightened fears among the Japanese public have actually given a boost to Prime Minister Abe and his ruling Liberal Democratic Party in a series of elections over the past decade. Observers point out that the North Korean card has been favorable to Japan's ruling party despite public anger over cronyism scandals linked to Shinzo Abe and wife. ${ }^{7}$ When the Korean peninsula remains a highly dangerous place, "Shinzo Abe keeps winning," ${ }^{8}$ which may explain Japan's modest enthusiasm for inter-Korean peace talks and possible diplomatic normalization between the United States and North Korea. While Japan, and especially the Abe government, seems to benefit politically from the maximum pressure policies advocated by the US and endorsed by the United Nations Security Council, it is the unpredictability of the Trump Administration, and Japanese fear to be excluded from a future settlement of the conflict, that is Tokyo's greatest

\footnotetext{
${ }^{4}$ Boc and Wacker, ibid., p. 31.

${ }^{5}$ Hilpert, Hanns Günther and Elli Pohlkamp: “Japan: On the Sidelines”, in Hilpert and Meier, op. cit., p. 36-39.

${ }^{6}$ Zone, Clark Freeport: "North Korea Threat is 'Critical and Imminent,' Japan Tells U.S., South Korea", Reuters, 23 October 2017, at https://www.aol.com/article/news/2017/10/23/north-korea-threat-is-critical-and-imminentjapan-tells-us-south-korea/23252392.; Osaki, Tomohiro and Daisuke Kikuchi: “Abe Declares 2020 as Goal for New Constitution", The Japan Times, 3 May 2019, at

https://www.japantimes.co.jp/news/2017/05/03/national/politics-diplomacy/abe-declares-2020-goal-newconstitution/\#.XXp2ky3MzBI.; Isozaki, Atsuhito: “Abe Left Behind on North Korea”, The Japan Times, 29 July 2019, at https://www.japantimes.co.jp/opinion/2019/07/29/commentary/japan-commentary/abe-administrationleft-behind-north-korea/\#.XXqDGS3MzBI.

${ }^{7}$ Sharp, Andy: "Japan Protesters Call for 'Liar' Abe to Resign over Scandal," Bloomberg, 14 April 2018 , at https://www.bloomberg.com/news/articles/2018-04-14/japanese-protesters-demand-liar-abe-s-resignation-overscandal.

8 Kingston, Jeff: "Shinzo Abe Keeps Winning", The Atlantic, 21 October 2017, at https://www.theatlantic.com/international/archive/2017/10/shinzo-abe-japan-military-article-9-northkorea/543546.
} 
concern. By narrowly focusing on the most hardline sanctions, mostly out of domestic political considerations, Japan runs the risk of becoming irrelevant in the possible solution of the conflict.

Japan's continuing political tension with South Korea adds another challenge to having Japan as a reliable and stable broker in the inter-Korean peace process. Tensions stem from matters, some old, some new, pertaining to Japan's government-led nationalist historiography, the contentious and emotional dispute over the islets, and "comfort women" -- the women who were forced to work in Imperial Japanese military brothels. As recently as 2019, the trade war between South Korea and Japan is, in a sense, a continuation of their political tension over history as it was primarily caused by South Korea's Supreme Court order that allows the South Korean victims of forced labor during World War II to seek compensation from Japanese companies. ${ }^{9}$ Japan retaliated by imposing tighter restrictions on critical exports to South Korean semiconductor companies and removing South Korea from its whitelist of favored economic partner. In response, South Korea pulled out of a bilateral intelligence sharing agreement with Japan, known as the General Security of Military Information Agreement (GSOMIA). ${ }^{10}$ On top of all this, tensions between Japan and North Korea are also far from being lessened. The issues range from Japan's wartime history, North Korea's nuclearization and relating missile tests over Japan, and the abductions of Japanese citizens by North Korea. Japan, as regional power does not have very good relations with South and North Korea. Domestic political considerations, and Japan's fear of being abandoned by the United States, push it back to the status quo.

Third, Russia's position is not too different from China's. In the post-cold war era, Russia no longer has enough political and economic leverage to influence North Korea. Nonetheless it does not want to be left behind in the new dynamics of the Korean peninsula. Sharing a border with North Korea, Russia has similar concerns as China does. Any radical changes in the North Korean regime may create an exodus of refugees and a mishandling of nuclear weapons. Also similar to China, Russia sees a unified Korea as inevitably becoming Washington's ally. This may increase the number of US bases on the Russian border. Russia has already experienced this when NATO approached Russian's border after the German unification and the pro-Western transformation of the Communist bloc. Russia, along with China, has suggested the idea of the so-called "double freeze," meaning that North Korea does not test any nuclear weapons or missiles and the United States and South Korea refrain from joint military exercises. ${ }^{11}$ This proposal intends to suspend the actions that irritated the other side most. Concerned about being marginalized by China and the United States, Russia is increasingly reaching out to both North and South Korea. ${ }^{12}$ Russia is interested in a possible

\footnotetext{
${ }^{9}$ Choe, Sang-Hun: "South Korean Court Orders Mitsubishi of Japan to Pay for Forced Wartime Labor", The New York Times, 29 November 2018, at https://www.nytimes.com/2018/11/29/world/asia/south-korea-wartimecompensation-japan.html.; Cho, Ki-weon and Park Min-hee: “Abe Expresses 'Dismay' at Forced Labor Victims Attempt to Seize Japanese Company Assets", Hankyoreh, 7 January 2019, at http://english.hani.co.kr/arti/english_edition/e_international/877347.html.

${ }^{10}$ Choi, Ha-yan: "No End in Sight for S. Korea's Economic Row with Japan”, Hankyoreh, 23 August 2019, at http://english.hani.co.kr/arti/english_edition/e_international/906872.html.; Johnson, Jesse and Sakura Murakami: "South Korea Decides to Exit Intelligence-Sharing Pact with Japan”, The Japan Times, 22 August, 2019, at https://www.japantimes.co.jp/news/2019/08/22/national/politics-diplomacy/south-korea-japan-intelligencesharing-pact-gsomia/\#.XZTyaC3MzBI.;Stangarone, Troy: "Korea's Dispute with Japan Spills into National Security", The Diplomat, 27 August 2019, at https://thediplomat.com/2019/08/koreas-dispute-with-japan-spillsinto-national-security.

11 “North Korea 'Dual Freeze' Plan Working, Russia's UN Envoy Says”, Russian News Agency TASS, 9 February 2018, at https://tass.com/politics/989330.; "US and N. Korea Following 'Double Freeze' Plan Proposed by Moscow and Beijing”, RT International, 20 June 2018, at https:/www.rt.com/news/430265-us-korea-doublefreeze-experts.

${ }^{12}$ Klein, Margarete: "Russia a Possible Mediator", in Hilpert and Meier, op. cit., p. 35.
} 
role as mediator, which will depend on the strength of its relations with both Koreas. Russia's interest stems mainly from the hope to gain from economic integration on a stable Korean peninsula.

In sum, Korea's direct neighbors, China, Japan, and Russia, have not always served as stable and constructive partners to improving the conditions for peace between the two Koreas. While all regional powers share an interest in negotiating a peaceful resolution to the nuclear crisis, national security considerations prevent the regional powers from moving beyond the present status quo. This becomes a key reason to seek support outside of the region, especially from the European Union and the Association of Southeast Asian Nations.

\section{The European Union as Mediator}

A good number of academic and policy papers describe the unique qualification of the European Union as possible mediator in the stalemate over North Korea's nuclear program or interKorean relations in general. ${ }^{13}$ The EU is, at first sight, not the most obvious candidate to attempt to broker peace through negotiated denuclearization on the Korean peninsula. It does not have a military presence in Asia and has limited trade relations with North Korea. The EU does participate in the ASEAN Regional Forum as one of the ASEAN dialogue partners, but it has often fails to speak with one voice as its member states frequently disagree on the best strategy in crisis situations. Europe's Common Foreign and Security Policy, initiated in the early 1990s to establish the Union as an international political actor, has been stalled by internal disagreements during the conflicts in Bosnia, Kosovo, and Iraq. It is therefore not evident how the EU, as "civilian power" can contribute to peace and security on the Korean peninsula. In the next section we will discuss the development of the relationship between the EU and North Korea, and assess the potential mediating role it can play. ${ }^{14}$ Given the strong diplomatic and trade relations between EU countries and South Korea, we will focus primarily on the European Union's relationship with North Korea, because therein lies the key to its potential role as mediator.

\subsection{Active Engagement: Europe's Diplomatic Embrace of North Korea}

The end of the Cold War saw closer relations between Europe and South Korea and the development of relations between China and Russia and South Korea. Whereas South Korea was developing diplomatic normalization with many new states, the North was becoming more isolated and lost its ideological and economic supporters. Acceptance into the United Nations, together with South Korea, was the only positive development for North Korea in the early 1990s. In the absence of improved relations with the rest of the world, including Europe, and with the loss of its superpower ally, the Soviet Union, North Korea sought to establish regime security through the development of nuclear weapons. Europe only began to pay attention to North Korea when it started nuclearization in earnest. Divided on how to respond, with

\footnotetext{
${ }^{13}$ Pardo, Ramon Pacheco: "The EU is Irrelevant in the Korean Peninsula, Rights? Wrong", Euroactiv (2008), at https://www.euractiv.com/section/european-external-action-service/opinion/thurs-the-eu-is-irrelevant-in-thekorean-peninsula-right-wrong.; Yoon, Young-Kwan and Ramon Pacheco Pardo: "Europe's North Korea Moment", Reuters, 17 October 2018, at https://www.reuters.com/article/us-youngkwan-koreacommentary/commentary-europes-north-korea-moment-idUSKCN1MR32T.; Novotna, Tereza and Allesandro Ford: "Donald Trump and Kim Jong-un Need the European Union", Bulletin of the Atomic Scientists, 3 May 2019 , at

https://thebulletin.org/2019/05/donald-trump-and-kim-jong-un-need-the-european-union.

${ }^{14}$ A different strain of research focuses on the European Union as model for peace and security building in East Asia. Bae, Sangmin and Martyn de Bruyn: "An Institutional Approach to Peace and Prosperity: Towards a Korean Fisheries Community", in Pascha, Werner and Bernhard Seliger (2011): Towards a Northeast Asian Security Community? Implications for Korea's Growth and Economic Development, Berlin: Springer, pp. 239-258. This section of the paper focuses exclusively on the role of the EU foreign and security policy with regard to nuclear proliferation on the Korean peninsula.
} 
sanctions or with talks, the EU supported the Clinton Administration's US-North Korean Framework Agreement in 1994. In 1997 the European Atomic Energy Agency (EURATOM) joined Korean Peninsula Energy Development Organization (KEDO) making contributions to the development of two light water nuclear power plants. South Korea, initially suspicious of the European collaboration with North Korea, embraced the European influence when President Kim Dae-jung came into power in 1998. The European Commission, in return, became a strong supporter of President Kim Dae-jung's Sunshine Policy, initiating the first-ever round of political talks with North Korea at the senior official level.

In 2001 the European Union established diplomatic relations with North Korea in return for a moratorium on missile testing until 2003. ${ }^{15}$ The EU engaged North Korea in an effort to ensure that the North would not restart its nuclear and missile programs. Europeans also wanted to show support for Kim Dae-jung, who, unlike previous South Korean presidents, genuinely supported European efforts to broker peace. Finally, Europeans were concerned that the Bush Administration would be far less willing to compromise with North Korea than the then departing Clinton Administration. ${ }^{16}$ European Union diplomatic recognition of North Korea, in addition to the establishment of diplomatic relations between North Korea and many EU member states, showed a more serious European engagement on the peninsula. ${ }^{17}$ Europeans hoped that a long-term engagement through humanitarian aid and development programs would persuade Pyongyang not to develop nuclear weapons and foster peace and stability between the two Koreas. North Korea had hoped that European recognition would send a message to the Bush Administration that the threat of hard power would be less effective than soft power incentives. Both North Korea and the Europeans would become disappointed by the lack of progress produced by the active engagement approach. President Bush's "axis of evil" speech showed that the establishment of diplomatic relations with the Europeans had not altered the American suspicion of the North, which is what the North Koreans had expected. By that time Pyongyang decided, instead of putting their trust in the Europeans, to double their effort to develop nuclear weapons in response to the threats from the United States. European Union officials, disappointed by this decision, tried to salvage their efforts by continuing to provide funding for the KEDO project as well as humanitarian aid. While some member states were favoring a more hardline approach, the European High Representative for Foreign and Security Policy, Javier Solana, argued that sanctions would not be helpful in defusing the crisis. ${ }^{18}$

\subsection{Europe Sidelined: Six-Party Talks}

As the US war in with Iraq in 2003 showed most dramatically the lack of unanimity between Europeans in the common foreign and security policy, momentum for European confidence building with North Korea waned. When North Korea was willing to attend the six-party talks in Beijing in 2003, Europeans were not invited to take part. This can be explained by two possible reasons. First, they did not have strategic or economic leverage on Pyongyang that would persuade North Korean leaders that the EU had something to offer that would strengthen their position vis-à-vis the US. Second, Europeans lacked a unified vision on how to diffuse the nuclear tension with North Korea. The absence of European unity on how to respond to North Korean provocations has weakened the European position. The fact that France, one of the leading member states in the area of foreign and security policy, does not maintain any

\footnotetext{
${ }^{15}$ Bridges, Brian: "Western Europe and North Korea: New Openings and Old Problems", East Asia, Vol. 20, nº 3 (September 2003), pp. 86-107.

${ }^{16}$ Arms Control Association, at https://www.armscontrol.org/factsheets/ 6partytalks.

${ }^{17}$ As of 2019 France and Estonia are the only EU member states that do not have diplomatic relations with North Korea.

${ }^{18}$ Bridges, op. cit., p.99.
} 
diplomatic relations with North Korea, and is often aligned with the United States and Japan pushing for hard sanctions, fragments the European Union's active engagement approach. ${ }^{19}$

When the six-party talks continued in 2004, trust between North Korea and the US was, however, severely lacking. The US insisted on complete, verifiable, and irreversible dismantlement (CVID) of the North's nuclear program, while Pyongyang remained unconvinced of American guarantees that it was not going to invade the North. ${ }^{20}$ Meanwhile American and European sanctions continued during the six-party talks. Talks continued even after North Korea's first nuclear test but eventually broke down in 2009 over disagreements over verification and international condemnation about North Korean missile testing.

The European Union launched its political dialogue with North Korea in 1998, in addition to it humanitarian mission, with the aim of establishing peace and security in between the two Koreas. The political dialogue continued during the years that North Korea was engaged in the six-party talks, during which the EU had an opportunity to discuss human rights and denuclearization with Pyongyang. However, because no major, or even minor, agreements have been accomplished the dialogue was suspended in 2015. The EU has not only provided humanitarian aid to North Korea, but also supported sanctions through the UN and even imposed its own independent sanction in 2006 and in 2018. ${ }^{21}$ The European Union's strategy toward North Korea has clearly become more punitive over time. The EU strategy changed from active engagement to critical engagement, meaning that the EU would set conditions on support and engagement other than humanitarian aid. ${ }^{22}$

\subsection{From Engagement to Sanctions}

Critical engagement also ended technical cooperation between EU and North Korea. The EU, fearful of North Korea successfully developing nuclear weapons, opted for a combination of incentives and coercive measures. The period of critical engagement saw a decrease in economic activity between Europe and North Korea and an increasing European focus on human rights abuses. The EU, following the lead from France and Ireland, increased the pressure on North Korea during the years of the six-party talks. The human rights conditions in North Korea, through EU leadership, became a significant matter for the United Nations. ${ }^{23}$ Following the first nuclear test in 2006 the UN Security Council, including two European states as permanent members, and two European states as non-permanent members, unanimously condemned the test and implemented sanctions against the North Korean regime. As North Korea continued to test nuclear devices and missiles, the UN Security Council, along with the European Union and other states, implemented more stinging sanctions against the regime. The balance between coercive measures and incentives definitively shifted in favor of the former. While the EU continued its critical engagement strategy until 2015, in reality the strategy could more aptly be referred to as active pressure. The EU suspended political dialogue with

\footnotetext{
${ }^{19}$ France was one of the leading states in negotiating the Joint Comprehensive Plan of Action (JCPOA), or Iran Nuclear Deal, in 2015. France and the United Kingdom, due to their size, and as permanent members of the UN Security Council, have had disproportionate influence on European foreign and security policy.

${ }^{20}$ Bridges, op. cit.; Harrison, Selig: "Did North Korea Cheat?", Foreign Affairs, Vol. 84, no 1 (January/February 2005), pp.99-110.

${ }^{21}$ ibid., p. 17.

${ }^{22}$ European External Action Service (EEAS), "DPRK and the EU”, European External Action Service (EEAS), (June 2016), at https://eeas.europa.eu/headquarters/headquarters-homepage/4186/dprk-and-eu_en.; Ko, Sangtu: "Vanguard of European Politics: The Role of Member States in the EU's Foreign Policy toward North Korea", Journal of International and Area Studies, Vol. 5, No. 1 (June 2018): pp. 47-59.

${ }^{23}$ Esteban, Mario: "The EU's Role in Stabilising the Korean Peninsula", Real Instituto Elcano Working Paper (January 2019), at http://www.realinstitutoelcano.org/wps/wcm/connect/49ffc71b-569c-4c88-bcabb9bffc485716/WP1-2018-Esteban-EU-role-stabilising-Korean-

Peninsula.pdf?MOD=AJPERES\&CACHEID=49ffc71b-569c-4c88-bcab-b9bffc485716\%20, p. 18.
} 
Pyongyang, reduced a number of cultural programs, and limited its role as aid donor by withdrawing European NGOs. ${ }^{24}$ The current policy of disengagement seems to be building on the idea that maximum pressure will force North Korea to give up its nuclear program and return to the Non-proliferation Treaty. The European Council's press statement, in the aftermath of North Korea's continued nuclear tests focused exclusively on hardline sanctions at the UN Security Council. It also specifically mentions the need for the universalization of the Comprehensive Nuclear-Test-Ban Treaty (CTBT), a treaty that is ratified by most EU member states, but opposed by the United States. ${ }^{25}$ The policy of active pressure has made the EU nearly indistinguishable from the US, and therefore less attractive as a possible mediator in resolving the nuclear crisis.

The initial expectation of the EU being a mediator between the United States and North Korea is in part raised by diplomatic relations that the European Union, as well as most member states, have with North Korea through which low level negotiations could lay the groundwork for a nuclear deal. The EU is also supposed to be a more trusted party, from Pyongyang's perspective, than the United States or Japan. An additional endorsement comes from the fact that the EU has a history and track record, in the case of Iran, as dealmaker in the denuclearization process. Unfortunately, the European support for maximum pressure policies of the US has undermined its position as honest broker. The Europeans may have had a reputation of trustworthy and engaged mediator in the 1990s, but they have not been able to limit American pressure or provide alternative policies that would have secured a deal with Pyongyang. The policies of critical engagement, and active pressure, have further sidelined the EU. Unless the European Commission and European leaders offer a meaningful alternative to the United States, Pyongyang might just as well negotiate with the US directly.

The Korean peninsula has, in comparison to the Middle East or Africa, not been a top priority for the European Union and its member states. The lack of priority, combined with internal divisions over Europe's common foreign and security approach to North Korea, has made Europe's response to the nuclear crisis mostly reactive. Europe had a potential critical role to play in getting to a denuclearized Korean peninsula, but has not positioned itself in a way that it can be most effective. Even if the top priority of the European Union is not necessarily peace on the Korean peninsula, Europe has a clear interest in bringing North Korea back into the Non-proliferation Treaty as non-nuclear state. The European Union can only protect the international architecture of non-proliferation if it engages with North Korea and builds trust in the process, although, this has not been the EU's chosen path in the past decade. The EU's policy of active pressure has not been most effective in attaining its goal of denuclearization. Because of these reasons the EU is not best positioned to serve as mediator in the nuclear crisis.

\section{ASEAN and Peace on the Korean Peninsula}

After World War II, the United States quickly built the alliance structure in Europe around the North Atlantic Treaty Organization (NATO) but preferred a bilateral approach with its Asian counterparts. ${ }^{26}$ Instead of seeking to form a multilateral security organization with Asian nations, Washington signed a separate defense treaty with each of its allies including Japan, South Korea, Taiwan, and the Philippines. In doing so, the Cold War played out very differently

\footnotetext{
${ }^{24}$ ibid., pp. 19-20.

${ }^{25}$ Council of the EU, "North Korea: Council Adopts Conclusions on the Democratic People's Republic of Korea (DPRK)", Press Release (December 2016), at https://www.consilium.europa.eu/en/press/pressreleases/2016/12/12/conclusions-dprk.

${ }^{26}$ Hemmer, Christopher and Peter J. Katzenstein: "Why is There No NATO in Asia? Collective Identity, Regionalism, and the Origins of Multilateralism”, International Organization, Vol. 56, n 3 (Summer 2002), pp. 575-607.
} 
for regional integration in Asia than it did for Europe. The Washington-dominated bilateral approach with Asian nations prevented the opportunity to build a multilateral institution in Asia and contributed to fragmentation in the region. Solingen described this important feature of Asian politics using the different terms of regionalism and regionalization. Whereas regionalism is developed around top-down driven formal institutions, regionalization is societally driven processes through bottom up, informal, diplomacy. Regionalism has been flourished in Europe since WWII with the development and consolidation of the European Union. Asian countries moved in a different direction to what is called regionalization. Unlike state-led formal regionalism, the driving force in regionalization comes from nonstate actors such as private companies and social organizations through commercial, cultural and human transactions. ${ }^{27}$

Undoubtedly, ASEAN, in comparison to EU, lacks enforcement power as it has virtually no criteria for membership and remains relatively free of binding and precise legal obligation. Strong emphasis on state sovereignty of member states indicates ASEAN's different organizational purpose compared to EU's. Promoting "perpetual peace, everlasting amity and cooperation" among the member states, ASEAN's Treaty of Amity and Cooperation (TAC) reaffirms the respect for state sovereignty, nonintervention, and renunciation of the threat of use of force in resolving disputes. ${ }^{28}$ While this emphasis on sovereignty and territorial integrity of member states largely explains ASEAN's weak binding authority as an international institution, it at the same time makes member states less confrontational and less hierarchical. ${ }^{29}$ In addition, due to its informal, inclusive nature, ASEAN can work closely with nonmember states in Asia contributing to widening regional cooperation and integration.

\subsection{ASEAN and South Korea's New Southern Policy}

ASEAN has maintained a neutral stance in inter-Korean matters. The fact that ASEAN has not taken a side in the past disputes between North and South Korea may make it an impartial and unbiased "middle man" in peace negotiations. In addition, ASEAN has great potential to contribute to inter-Korean relations due to its traditional and growing relations with both South and North Korea. We will address the development of South Korea's relations with ASEAN and Southeast Asia in this section and explore the important historical and continuing ties between North Korea and ASEAN in the following section.

Since President Moon Jae-in came in office in 2017, the South Korea government has sought to further expand ties with South and Southeast Asian countries through "New Southern Policy." In doing so, ASEAN has become its central partner. While South Korea's interest in ASEAN and Southeast Asia is not completely new, mainly due to existing active economic relations, the Moon government's objective of North Korea engagement through ASEAN is a new feature in Seoul's Southeast Asian policy. Certainly, the Moon government further recognizes ASEAN's importance in managing challenges in inter-Korean relations and in advancing opportunities as part of its wider middle power diplomatic efforts. Unlike previous administrations where South Korea's diplomacy was disproportionally focused on major powers in geographic proximity, the Moon government aims to elevate stronger political and economic ties with countries in South and Southeast Asia to a similar level of relations it has

\footnotetext{
${ }^{27}$ Solingen, Etel: "East Asian Regional Institutions: Characteristics, Sources, Distinctiveness", in Pempel, T.J. (ed.) (2005): Remapping Asia: Competing Patterns of Regional Integration, Cornell University Press, pp. 31-53. ${ }^{28}$ ASEAN, "Treaty of Amity and Cooperation in Southeast Asia" (24 February 1976), at https://asean.org/treatyamity-cooperation-southeast-asia-indonesia-24-february-1976.

${ }^{29}$ Solingen, op. cit., p. 46.
} 
with the United States, China, Japan, and Russia. ${ }^{30}$ The Moon government's drive to widen its diplomatic horizons is a strategic choice to mitigate negative impacts from the major powers competing for primacy in the region. South Korea's diplomatic rift with its neighbors in the region, discussed above, also makes ASEAN an attractive, complementary partner.

South Korea's New Southern Policy follows the guiding principle of "3Ps"-- people, peace, and prosperity. ${ }^{31}$ Among the elements of 3Ps, people and prosperity are in line with what ASEAN has been promoting -- sociocultural exchanges and human mobility flows ("people") and economic cooperation ("prosperity"). ASEAN is South Korea's second largest trading partner and the third largest investment partner. Since the free trade agreement was signed between South Korea and 10 ASEAN nations in 2007, the volume of trade has jumped substantially. South Korea's trade volume with ASEAN in 2018 amounted to \$150 billion USD, which represents 15 percent of Korea's total trade -- increased from 9.9 percent in 2007. This trade volume is expected to be even higher with a set goal of $\$ 200$ billion USD by $2020 .{ }^{32}$ South Korea is also one of the leading providers of official development assistance (ODA) for ASEAN nations. In May 2019, the Korea International Cooperation Agency (KOICA) announced its plan to increase ODA to its ASEAN partner countries by 20 percent every year and therefore double the total amount it contributes by $2023 .{ }^{33}$ Sociocultural cooperation and people-topeople exchanges are equally impressive. The number of visitors is fast growing between the two sides surpassing 10 million annually. ${ }^{34}$ The emphasis on people also represents President Moon's campaign slogan and key policy principle, "people come first (not money or status)." 35

In South Korea's New Southern Policy, the third "P" for peace is a new addition to its relations with ASEAN. ASEAN countries have not been actively involved in security issues in the Korean peninsula mainly because ASEAN and Korea do not share common security threats. ${ }^{36}$ Unlike NATO that was built to address common threats and challenges, many Asian nations lack a commonality in security threats and conditions. This may explain why the cooperation in political and security areas between ASEAN and South Korea has lagged behind in comparison to the areas of economic cooperation and socio-cultural exchanges. Newly added peace cooperation, rather than cooperation for traditional security, is also an alternative, diplomatic discourse that might be more easily agreed by middle and small power countries. The discourse of peace cooperation and its related policy, rather than any security-oriented

\footnotetext{
${ }^{30}$ Whiteside, Darren: "South Korea's Moon Unveils New Focus on Southeast Asia", Reuters, 9 November 2017, at https://www.reuters.com/article/us-indonesia-southkorea/south-koreas-moon-unveils-new-focus-on-southeastasia-idUSKBN1D900C.

${ }^{31}$ Presidential Committee on New Southern Policy: "Directions for Promoting the New Southern Policy", at http://nsp.go.kr/eng/policy/policy02Page.do.

${ }^{32}$ South Korean Ministry of Trade, Industry and Energy: "ASEAN Became Korea's Second Largest Trading Partner under FTA", 2 June 2017, at http://english.motie.go.kr/www/main.do.; "Trade between S. Korea, ASEAN to Top $\$ 160 \mathrm{~b}$ This Year", Yonhap News, 26 November 2018, at http://www.koreaherald.com/view.php?ud=20181126000832.; Suk-yee, Jung: "Trade between ASEAN Region and S. Korea is Expanding Rapidly", Business Korea, 10 November 2017, at http://www.businesskorea.co.kr/news/articleView.html?idxno=19775.

33 "S. Korea's Aid Agency to Double ODA to ASEAN Countries by 2023", Yonhap News, 17 May 2019, at https://en.yna.co.kr/view/AEN20190517009000325.

34 ASEAN-Korea Centre, "Visitors between ASEAN and Korea", 2019, at https://www.aseankorea.org/eng/Resources/figures.asp.; Srimalee, Somluck: "Tourism Dollars Flow between S Korean and ASEAN", The Nation, 7 June 2018, at https://www.nationthailand.com/Economy/30347236.

${ }^{35}$ Moon Jae-in: "Keeping My Promises to the People", Korean Culture and Information Services (June 2018), at http://www.kocis.go.kr/eng/webzine/201806/sub07.html.

${ }^{36}$ Lee, Jaehyon, "Korea's New Southern Policy: Motivations of 'Peace Cooperation' and Implications for the Korean Peninsula", Issue Briefs, The Asian Institute for Policy Studies (June 2019), at http://en.asaninst.org/contents/koreas-new-southern-policy-motivations-of-peace-cooperation-and-implicationsfor-the-korean-peninsula/\#a37.
} 
approach, might be far more attainable among regional middle and small powers like ASEAN and the two Koreas and be less guided by superpower influence. ${ }^{37}$ The three pillars of "people, prosperity and peace" in South Korea's New Southern Policy present an opportunity for ASEAN's positive and constructive involvement in inter-Korean relations.

\subsection{ASEAN and North Korean Relations}

ASEAN's role in the Korean peninsula is also promising because of its relatively strong connection with Pyongyang. In the past decades North Korea has suffered from economic sanctions mainly imposed by the United Nations Security Council. While we often call North Korea a country of "growing international isolation," it has long enjoyed diplomatic and trade relations with ASEAN countries. With the only exceptions of the Philippines and Brunei, North Korea has embassies and diplomatic personnel in all other ASEAN member countries such as Cambodia, Indonesia, Laos, Myanmar, Singapore, Thailand and Vietnam. ${ }^{38}$ Many of these countries were built based on socialist political ideology, with which North Korea has a natural bond.

ASEAN-led multilateral forum has been a vital channel for communication between North Korea and the international community. The ASEAN Regional Forum (ARF) is one of a few multilateral platforms where North Korea is an active member. Comprised of twenty-seven nations - the ten ASEAN member states, the ten dialogue partners including the US, the EU, China and Japan, and seven other countries in the region including the two Koreas - the ARF discusses security concerns and measures to reduce regional tensions. The ARF has five work streams including non-proliferation and disarmament. While counter-terrorism and maritime security in the South China Sea were the two main discussion topics at the ARF ministerial meeting in 2019, peace on the Korean peninsula was also on the agenda. The Chairman's statement both welcomed the dialogue between the United States and North Korea and urged the North to commit to denuclearization. The statement also urged all parties to work towards a lasting peace that would bring peace and stability in the region. ${ }^{39}$ The broad representation of member states in the ARF and the established connection between North Korea and many ASEAN member states make ASEAN a credible mediator in the process of peace negotiations and denuclearization on the Korean peninsula.

In the long term, ASEAN's involvement can also shed light on the future trajectory of economic development in North Korea. ASEAN members, such as Vietnam, Cambodia and Laos, probably more so than China, will be North Korea's model for future economic reform and international integration. While China is considered to be a "successful" model of embracing capitalism without threatening the rule of the one-party state, North Korea, in terms of its economy scale, capacity, and geopolitical conditions, is vastly different from China. Instead, Vietnam, for instance, is more comparable for North Korea not only because of the relative size of their economy but also due to the potential influence of the United States. While China continues to seek greater economic autonomy from the United States, and it has the capability to do so, Vietnam, a former enemy of the United States, now actively builds bilateral trade and investment arrangements with the US. North Korea, expecting future economic ties with South Korea, a strong political and economic ally of the United States, will likely to be integrated into the US-led economic structure, if North Korea's reform continues. In sum, given the positive track record between North Korea and ASEAN, North Korea would feel

\footnotetext{
${ }^{37}$ Lee, op. cit.

${ }^{38}$ East-West Center and the National Committee on North Korea, "North Korea in the World: North Korea's External Relations", at https://www.northkoreaintheworld.org/home.

${ }^{39}$ ASEAN Regional Forum: "Chairman's Statement of the $26^{\text {th }}$ ASEAN Regional Forum”, (August, 2019), at https://www.asean2019.go.th/en/news/chairmans-statement-of-the-26th-asean-regional-forum-bangkok-2august-2019.
} 
comfortable getting ASEAN involved in inter-Korean matters. ${ }^{40}$ It was not just a coincidence that the first two summits between the United States and North Korea took place in ASEAN countries -- Singapore and Vietnam. ASEAN is seen as a trusted ally to Pyongyang, therefore as having a great potential to help to integrate North Korea into the peaceful regional community.

\section{Conclusion}

The Trump Administration's bold move to initiate direct bilateral negotiations with North Korea presented a radical break from both their own hard confrontational approach that preceded the talks, and from the American approach of isolating the North preferred by previous administrations. The immediate beneficiary from the talks has been South Korea, which saw a dramatic reduction in tensions and a halt in nuclear and missile testing in exchange for a halt in US-South Korean military exercises. Tension reduction is critical for a process of confidence building between negotiating parties, but it has not provided North Korea with a direct incentive to give up its nuclear program. Bilateral negotiations have been instrumental to break the status quo and start a new process that can end North Korea's isolation in exchange for ending its nuclear program. Without the first step of bilateral talks North Korea would remain a nuclear power operating mostly in isolation from the international community.

However, in order for the North to give up its nuclear ambitions, which it sees as a selfdefense measure against US-led outside enforced regime change, as witnessed in Iraq and Libya, it needs a robust security guarantee. The bilateral framework is unlikely to produce such a guarantee because the United States would require complete, verifiable, and irreversible dismantlement (CVID) of nuclear weapons conditional upon this. This is where a multilateral approach becomes preferable because a party, other than the United States or North Korea, can hold both states accountable. The regional powers surrounding the Korean peninsula have, for the reasons discussed above, not been able to play a meditating role between the United States and North Korea, or between South and North Korea. The European Union and its active pressure policies, as discussed earlier, have made it virtually indistinguishable from the United States and thus unfit to serve in a mediating role. ASEAN, on the other hand, can potentially play an important role in the negotiating process in getting the North secure enough to relinquish its nuclear program. There are a number of reasons why ASEAN might hold the key to moving beyond the status quo on peace building on the Korean peninsula. ASEAN is perceived by Pyongyang as more neutral than the United States or any regional powers in Northeast Asia. The European Union also benefitted from perceived neutrality during the 1990s, but since the implementation of its sanctions regime this has significantly changed. ASEAN has good, and further developing, relations with both North and South Korea: "With strong ties to both Koreas, ASEAN is perfectly positioned to act as a 'middle-man' between the North and South." ${ }^{41}$ As middle power states, ASEAN members are perceived to have similar interests as the two Koreas. In terms of development trajectory, ASEAN member states, such as Vietnam, are more realistic models for North Korea to emulate. It should be acknowledged that any engagement in good offices by ASEAN can only be successful with the tacit understanding of China. China would not want to see its position of relative influence with respect to North Korea challenged by ASEAN, however. For China to support ASEAN's good offices it would have to prefer ASEAN's new role over a potential direct US led peace deal

\footnotetext{
${ }^{40}$ Lee, op. cit.

${ }^{41}$ ASEAN, "ASEAN: The Reluctant 'Middle-Man' in the Inter-Korean Peace Process", ASEAN Today (December 2018), at https://www.aseantoday.com/2018/12/asean-the-reluctant-middle-man-in-the-inter-korean-peaceprocess.
} 
with North Korea. While at present China seems to prefer the status quo on the Korean peninsula, it would rather support dialogue, through ASEAN, on which it can assert some influence, over any US-led initiative that could substantively diminish China's influence in the region.

The multilateral approach, as exercised through the six-party talks was mostly unsuccessful because the regional powers were more concerned with their own strategic positions and interests than with bringing peace and stability to the two Koreas. ASEAN member states do not have the same regional power considerations that would undermine their role as mediators. Perhaps most importantly, ASEAN has not been focused solely on denuclearization, but understands, through its own focus on sovereignty and non-interference, that North Korea needs to have a substantive security assurance before it will negotiate away its nuclear arsenal. ASEAN can refocus the discussion on peace building, and the development of economic ties between itself and the two Koreas, without having any security guarantees be dependent on CVID. Direct talks between Washington and Pyongyang have pushed the regional powers in Asia to think beyond the status quo. It is a new and promising idea that ASEAN can fulfill a meaningful role as mediator to improve trust and bring a secure peace deal to the Korean peninsula. While the question of how specifically and to what extent ASEAN will play its role still remains unanswered, the opportunity is greater than ever before.

\section{Bibliography}

Arms Control Association, at https://www.armscontrol.org/factsheets/ 6partytalks.

ASEAN: “ASEAN: The Reluctant 'Middle-Man' in the Inter-Korean Peace Process", ASEAN Today (December 2018), at https://www.aseantoday.com/2018/12/asean-the-reluctant-middleman-in-the-inter-korean-peace-process.

ASEAN: "Treaty of Amity and Cooperation in Southeast Asia" (February 1976), at https://asean.org/treaty-amity-cooperation-southeast-asia-indonesia-24-february-1976.

ASEAN-Korea Centre: "Visitors between ASEAN and Korea", 2019, at https://www.aseankorea.org/eng/Resources/figures.asp.

ASEAN Regional Forum (ARF): "Chairman's Statement of the $26^{\text {th }}$ ASEAN Regional Forum" (August, 2019), at https://www.asean2019.go.th/en/news/chairmans-statement-of-the-26thasean-regional-forum-bangkok-2-august-2019.

Bae, Sangmin and Martyn de Bruyn: "An Institutional Approach to Peace and Prosperity: Towards a Korean Fisheries Community”, in Pascha, Werner and Bernhard Seliger (2011): Towards a Northeast Asian Security Community? Implications for Korea's Growth and Economic Development, Berlin, Springer, pp. 239-258.

Boc, Anny and Gudrun Wacker: "China: Between Key Role and Marginalization”, in Hilpert, Hanns Günther and Oliver Meier (eds.) (2018): Facets of the North Korea Conflict: Actors, Problems, and Europe's Interests, Stiftung Wissenschaft und Politik (SWP) Research Paper 12, at https://www.swp-berlin.org/en/publication/facets-of-the-north-korea-conflict., pp. 27-30.

Bridges, Brian: "Western Europe and North Korea: New Openings and Old Problems", East Asia, Vol. 20, nº 3 (September 2003), pp. 86-107.

Cho, Ki-weon and Park Min-hee: “Abe Expresses 'Dismay' at Forced Labor Victims Attempt to Seize Japanese Company Assets", Hankyoreh, 7 January 2019, at http://english.hani.co.kr/arti/english_edition/e_international/877347.html. 
Choe, Sang-Hun: "South Korean Court Orders Mitsubishi of Japan to Pay for Forced Wartime Labor", The New York Times, 29 November 2018, at https://www.nytimes.com/2018/11/29/world/asia/south-korea-wartime-compensationjapan.html.

Choi, Ha-yan: "No End in Sight for S. Korea's Economic Row with Japan”, Hankyoreh, 23 August 2019, at http://english.hani.co.kr/arti/english_edition/e_international/906872.html.

Council of the EU, "North Korea: Council Adopts Conclusions on the Democratic People's Republic of Korea (DPRK)", Press Release (December 2016), at https://www.consilium.europa.eu/en/press/press-releases/2016/12/12/conclusions-dprk.

East-West Center and the National Committee on North Korea, "North Korea in the World: North Korea's External Relations", at https://www.northkoreaintheworld.org/home.

Esteban, Mario: “The EU's Role in Stabilising the Korean Peninsula”, Real Instituto Elcano Working Paper (January 2019), at http://www.realinstitutoelcano.org/wps/wcm/connect/49ffc71b-569c-4c88-bcabb9bffc485716/WP1-2018-Esteban-EU-role-stabilising-Korean-

Peninsula.pdf?MOD=AJPERES\&CACHEID=49ffc71b-569c-4c88-bcab-b9bffc485716\%20, pp. 1-44.

European External Action Service (EEAS): "DPRK and the EU”, European External Action Service (EEAS), (June 2016), at https://eeas.europa.eu/headquarters/headquartershomepage/4186/dprk-and-eu_en.

Harrison, Selig: “Did North Korea Cheat?", Foreign Affairs, Vol. 84, no 1 (January/February 2005), pp.99-110.

Hemmer, Christopher and Peter J. Katzenstein: "Why is There No NATO in Asia? Collective Identity, Regionalism, and the Origins of Multilateralism", International Organization, Vol. $56, n^{\circ} 3$ (Summer 2002), pp. 575-607.

Hilpert, Hanns Günther and Elli Pohlkamp: "Japan: On the Sidelines", in Hilpert, Hanns Günther and Oliver Meier (eds.) (2018): Facets of the North Korea Conflict: Actors, Problems, and Europe's Interests, Stiftung Wissenschaft und Politik (SWP) Research Paper 12, at https://www.swp-berlin.org/en/publication/facets-of-the-north-korea-conflict., pp. 36-39.

Isozaki, Atsuhito: "Abe Left Behind on North Korea", The Japan Times, 29 July 2019, at https://www.japantimes.co.jp/opinion/2019/07/29/commentary/japan-commentary/abeadministration-left-behind-north-korea/\#.XXqDGS3MzBI.

Johnson, Jesse and Sakura Murakami: "South Korea Decides to Exit Intelligence-Sharing Pact with Japan", The Japan Times, 22 August, 2019, at https://www.japantimes.co.jp/news/2019/08/22/national/politics-diplomacy/south-koreajapan-intelligence-sharing-pact-gsomia/\#.XZTyaC3MzBI.

Kim, Patricia: "How China Sees North Korea: Three Critical Moments in History and Future Directions", The Chicago Council on Global Affairs (January 2018), at https://www.thechicagocouncil.org/publication/how-china-sees-north-korea-three-criticalmoments-history-and-future-directions.

Kingston, Jeff: "Shinzo Abe Keeps Winning", The Atlantic, 21 October 2017, at https://www.theatlantic.com/international/archive/2017/10/shinzo-abe-japan-military-article9-north-korea/543546.

Klein, Margarete: "Russia a Possible Mediator", in Hilpert, Hanns Günther and Oliver Meier (eds.) (2018): Facets of the North Korea Conflict: Actors, Problems, and Europe's Interests, 
Stiftung Wissenschaft und Politik (SWP) Research Paper 12, at https://www.swpberlin.org/en/publication/facets-of-the-north-korea-conflict., p. 31-35.

Ko, Sangtu: "Vanguard of European Politics: The Role of Member States in the EU's Foreign Policy toward North Korea", Journal of International and Area Studies, Vol. 5, no 1 (June 2018): pp. 47-59.

Lee, Jaehyon, 'Korea's New Southern Policy: Motivations of 'Peace Cooperation' and Implications for the Korean Peninsula", Issue Briefs, The Asian Institute for Policy Studies (June 2019), at http://en.asaninst.org/contents/koreas-new-southern-policy-motivations-ofpeace-cooperation-and-implications-for-the-korean-peninsula/\#a37.

Liu, Ming: "China and the North Korean Crisis: Facing Test and Transition", Pacific Affairs, Vol. 76, No. 3 (Fall 2003), pp. 347-373.

Moon Jae-in: "Keeping My Promises to the People", Korean Culture and Information Services (June 2018), at http://www.kocis.go.kr/eng/webzine/201806/sub07.html.

“North Korea 'Dual Freeze' Plan Working, Russia's UN Envoy Says”, Russian News Agency TASS, 9 February 2018, at https://tass.com/politics/989330.

Novotna, Tereza and Allesandro Ford: "Donald Trump and Kim Jong-un Need the European Union", Bulletin of the Atomic Scientists, 3 May 2019, at https://thebulletin.org/2019/05/donald-trump-and-kim-jong-un-need-the-european-union.

Osaki, Tomohiro and Daisuke Kikuchi: "Abe Declares 2020 as Goal for New Constitution”, The Japan Times, 3 May 2019, at

https://www.japantimes.co.jp/news/2017/05/03/national/politics-diplomacy/abe-declares2020-goal-new-constitution/\#.XXp2ky3MzBI.

Pardo, Ramon Pacheco: "The EU is Irrelevant in the Korean Peninsula, Rights? Wrong”, Euroactiv (2008), at https://www.euractiv.com/section/european-external-actionservice/opinion/thurs-the-eu-is-irrelevant-in-the-korean-peninsula-right-wrong.

Park, Hun-Bong: "China's Position on Korea's Unification and US Forces Korea”, The Journal of East Asian Affairs, Vol. 24, nº 1 (Spring/Summer 2010), pp. 117-154.

Presidential Committee on New Southern Policy: "Directions for Promoting the New Southern Policy", at http://nsp.go.kr/eng/policy/policy02Page.do.

Sharp, Andy: "Japan Protesters Call for 'Liar' Abe to Resign over Scandal," Bloomberg, 14 April 2018, at https://www.bloomberg.com/news/articles/2018-04-14/japanese-protestersdemand-liar-abe-s-resignation-over-scandal.

"S. Korea's Aid Agency to Double ODA to ASEAN Countries by 2023", Yonhap News, 17 May 2019, at https://en.yna.co.kr/view/AEN20190517009000325.

Solingen, Etel: "East Asian Regional Institutions: Characteristics, Sources, Distinctiveness", in Pempel, T.J. (ed). (2005): Remapping Asia: Competing Patterns of Regional Integration, Cornell University Press, pp. 31-53.

South Korean Ministry of Trade, Industry and Energy: "ASEAN Became Korea's Second Largest Trading Partner under FTA" (June 2017), at http://english.motie.go.kr/www/main.do. 
Srimalee, Somluck: "Tourism Dollars Flow between S Korean and ASEAN", The Nation, 7 June 2018, at https://www.nationthailand.com/Economy/30347236.

Stangarone, Troy: "Korea's Dispute with Japan Spills into National Security", The Diplomat, 27 August 2019, at https://thediplomat.com/2019/08/koreas-dispute-with-japan-spills-intonational-security.

Suk-yee, Jung: "Trade between ASEAN Region and S. Korea is Expanding Rapidly", Business Korea, 10 November 2017, at

http://www.businesskorea.co.kr/news/articleView.html?idxno=19775.

"Trade between S. Korea, ASEAN to Top \$160b This Year", Yonhap News, 26 November 2018, at http://www.koreaherald.com/view.php?ud=20181126000832.

“US and N. Korea Following 'Double Freeze' Plan Proposed by Moscow and Beijing", $R T$ International, 20 June 2018, at https://www.rt.com/news/430265-us-korea-double-freezeexperts.

Whiteside, Darren: "South Korea's Moon Unveils New Focus on Southeast Asia”, Reuters, 9 November 2017, at https://www.reuters.com/article/us-indonesia-southkorea/south-koreasmoon-unveils-new-focus-on-southeast-asia-idUSKBN1D90OC.

Yoon, Young-Kwan and Ramon Pacheco Pardo: "Europe's North Korea Moment", Reuters, 17 October 2018, at

https://www.reuters.com/article/us-youngkwan-korea-commentary/commentary-europesnorth-korea-moment-idUSKCN1MR32T.

Zone, Clark Freeport: "North Korea Threat is 'Critical and Imminent,' Japan Tells U.S., South Korea", Reuters, 23 October 2017, at https://www.aol.com/article/news/2017/10/23/northkorea-threat-is-critical-and-imminent-japan-tells-us-south-korea/23252392. 